\title{
Article \\ Effect of Fertilisation with Ash from Biomass Combustion on the Mechanical Properties of Potato Tubers (Solanum tuberosum L.) Grown in Two Types of Soil
}

\author{
Ewa Szpunar-Krok ${ }^{1, *}$, Małgorzata Szostek ${ }^{2}$ D, Renata Pawlak $^{1}$, Józef Gorzelany ${ }^{3}$ and Dagmara Migut ${ }^{1}$ D \\ 1 Department of Plant Production, University of Rzeszow, Zelwerowicza 4, 35-601 Rzeszów, Poland; \\ pawlak_renata@o2.pl (R.P.); dmigut@ur.edu.pl (D.M.) \\ 2 Department of Soil Science, Environmental Chemistry and Hydrology, University of Rzeszow, \\ Zelwerowicza 8b, 35-601 Rzeszów, Poland; mszostek@ur.edu.pl \\ 3 Department of Food and Agriculture Production Engineering, University of Rzeszow, Zelwerowicza 4, \\ 35-601 Rzeszów, Poland; jgorzelany@ur.edu.pl \\ * Correspondence: eszpunar@ur.edu.pl
}

check for updates

Citation: Szpunar-Krok, E.; Szostek, M.; Pawlak, R.; Gorzelany, J.; Migut, D. Effect of Fertilisation with Ash from Biomass Combustion on the Mechanical Properties of Potato Tubers (Solanum tuberosum L.) Grown in Two Types of Soil. Agronomy 2022, 12, 379. https://doi.org/10.3390/ agronomy12020379

Academic Editor: Danilo Scordia

Received: 30 December 2021

Accepted: 28 January 2022

Published: 3 February 2022

Publisher's Note: MDPI stays neutral with regard to jurisdictional claims in published maps and institutional affiliations.

Copyright: (C) 2022 by the authors. Licensee MDPI, Basel, Switzerland. This article is an open access article distributed under the terms and conditions of the Creative Commons Attribution (CC BY) license (https:// creativecommons.org/licenses/by/ $4.0 /)$.

\begin{abstract}
The aim of the research was to determine the effect of fertilising with various doses of ash from biomass combustion (D2-D6) compared to control plots and classic NPK (D1) fertiliser on the morphological and mechanical properties of potato tubers (Solanum tuberosum L.). The field experiment was carried out in the years 2019-2021 (south-eastern Poland, $49^{\circ} 59^{\prime} \mathrm{N}, 21^{\circ} 57^{\prime} \mathrm{E}$ ) on two types of soil: Gleyic Chernozem (silty loam) and Haplic Luvisol (silt). The values of mechanical parameters, such as the peel and flesh punching force $\left(F_{D}\right)$, deformation $\left(D_{R}\right)$ and energy $\left(E_{D}\right)$ needed to destroy the test sample, were assessed. The biometric features of the tubers were also assessed. It was found that tubers obtained from the experimental fields where D3 and D4 ash fertiliser doses were applied (corresponding to doses of 188 and $282 \mathrm{~kg} \cdot \mathrm{ha}^{-1} \mathrm{~K}$ ) had the highest tuber yields and the highest resistance to mechanical damage under quasi-static loads. Ash from biomass combustion can be an alternative to conventional mineral fertilizers and can be used in the development of mineral fertilization plans for sustainable agriculture, which will help to solve the problem of storage of this waste.
\end{abstract}

Keywords: biomass ash; fertilisation; potatoes; mechanical properties

\section{Introduction}

The potato tuber (Solanum tuberosum L.) is a leading tuberous plant with beneficial nutritional properties that is cultivated in different environments in over 100 countries around the world. It is a basic food product of great economic and nutritional value. It ranks fifth among agricultural crops, after rice, wheat, maize and sugarcane [1-6]. There is a wide variety of different forms of potato with various botanical and functional characteristics. Different varieties of the same species may contain different nutrients and bio compounds $[7,8]$, which largely depend on the application of properly selected and balanced mineral fertilisers. Due to the increasing use of wood, the amount of waste products, such as wood ash, has increased $[9,10]$. The use of wood ash as an additive to mineral fertilisers contributes to the return of valuable nutrients to agricultural soils, especially when no artificial mineral fertilisers are used. Solid biomass, including wood, contains various inorganic components in different amounts and specifications. Ash obtained from wood biomass contains a variety of elements, incl. phosphorus, potassium, calcium, zinc and other components, but their concentration in the ash depends on the tree species, the part of the tree and the harvest season $[11,12]$. Bottom ash is considered problem-free and is sometimes used as a fertiliser additive as it contains valuable nutrients [13].

Obtaining higher and higher yields of the best quality is one of the basic goals of modern agriculture. An equally important goal is the reduction of losses during the 
production and processing of raw materials. The study of mechanical properties allows the quality of the raw material, its firmness and hardness, to be determined which is used to assess the post-harvest quality [14-16], predicting internal mechanical reactions (e.g., the evolution of damage) during various technological processes $[17,18]$ as well as the development of new solutions in washing, sorting and packaging machines $[19,20]$. The texture of fruits and vegetables is derived from turgor pressure, the composition of the individual plant cell walls, and the middle cell lamina that holds the individual cells together [21]. The chemical and structural properties of plant tissues have an impact on the quality of potato tubers. The quality of tubers varies greatly and depends on factors such as climate, growing conditions, variety and maturity at harvest and harvesting method [22]. Quasi-static mechanical tests are widely used to obtain objective data on the mechanical and textural properties of vegetables [23]. Plant raw materials show a visco-elastic behaviour under mechanical stress, which depends both on the force applied and the speed of the load. However, the behaviour can be considered elastic in the first part of the load-strain curve, where the stress-strain relationship is linear under quasi-static conditions [24]. Early identification of factors impacting raw material damage permits the making of decisions on the production flow in order to reduce significant economic losses [25-28]. The results of studies on the fertilization of ash from biomass combustion on the crop yield are available, but there is no information about its influence on the post-harvest quality of agricultural crops expressed in mechanical parameters. Therefore, the aim of the research was to determine the effect of fertilising with ash from biomass combustion in various doses (according to the amount of $\mathrm{K}_{2} \mathrm{O}$ applied to the soil) on the selected mechanical properties of potato tubers.

\section{Materials and Methods}

\subsection{Field Experiment Description}

Field experiments were carried out in 2019-2021. They were located on a private farm in south-eastern Poland $\left(50^{\circ} 3^{\prime} \mathrm{N}, 22^{\circ} 47^{\prime}\right.$ E; Figure 1). The experiments were two-factor in a randomised block design with four replications (plot area $40.5 \mathrm{~m}^{2}$ ). The research factors were:

I. Type of soil: Gleyic Chernozem and Haplic Luvisol,

II. Different fertiliser treatments of the potatoes (cv. Sagitta, mid-early, edible, culinary type-French fries, breeder HZPC Holland B.V., Joure, The Netherlands): Control plots—only N and P fertiliser; D1-NPK mineral fertiliser; D2-D6- N and P mineral fertiliser + ash from biomass with different doses: $0.5,1.0,1.5,2.0,2.5 \mathrm{t} \cdot \mathrm{ha}^{-1}$, respectively.

The forecrop for potatoes was spring barley. After harvesting the forecrop, the site was first ploughed. In autumn, the relevant plots were fertilised with ash from biomass combustion and this was mixed with the soil during pre-winter ploughing (approx. $25-30 \mathrm{~cm}$ ). In spring, pre-sowing mineral fertilisers were applied and mixed with the soil using a cultivator. Mineral fertilisation with nitrogen was constant (the same doses for all variants of the experiment). Nitrogen was used in the form of $\mathrm{RSM}^{\circledR} 32 \% \mathrm{~N}$ (aqueous solution of urea ammonium nitrate, density $1.32 \mathrm{~kg} \cdot \mathrm{dm}^{-3}$ ) and monoammonium phosphate (MAP) $\mathrm{NH}_{4} \mathrm{H}_{2} \mathrm{PO}_{4}\left(12 \% \mathrm{~N}-\mathrm{NH}_{4}\right)$. Phosphorus was introduced into the soil in the form of monoammonium phosphate (MAP, 22.7\% P) and with biomass ash (according to experimental objects D2-D6). In variant D1, mineral fertilisation in the form of potassium salt $(60 \%)$ was used. Fly ash collected from an electrostatic precipitator (ESP) was burned in a fluidised bed furnace for this experiment. The ash came from the combustion of forest $(70 \%)$ and agricultural biomass (30\%). The forest biomass consisted of deciduous and coniferous trees, and the agricultural biomass was cereal straw, sunflower husk and willow. The ash $\mathrm{pH}$ was 12.8. It was characterized by fine graining. The clay-dust fraction (from $<0.002$ to $0.05 \mathrm{~mm}$ ) accounted for about $90 \%$, and the sand fraction (from 0.05 to $2 \mathrm{~mm}$ ) accounted for $10 \%$ of the fly ash mass. According to the CLP Regulation (EC) No.1272/2008, it is not a hazardous substance, it does not pose a threat to human health and the environment. The mineral composition of the ash is given in Table S1. The amount of nutrients supplied 
to the soil each year is presented in Table 1. Potatoes were planted in the second or third decade of April, when the soil at a depth of $10 \mathrm{~cm}$ reached about $6-8^{\circ} \mathrm{C}$, with a density of 40 thousand plants per ha, with a row spacing of $62.5 \mathrm{~cm}$.
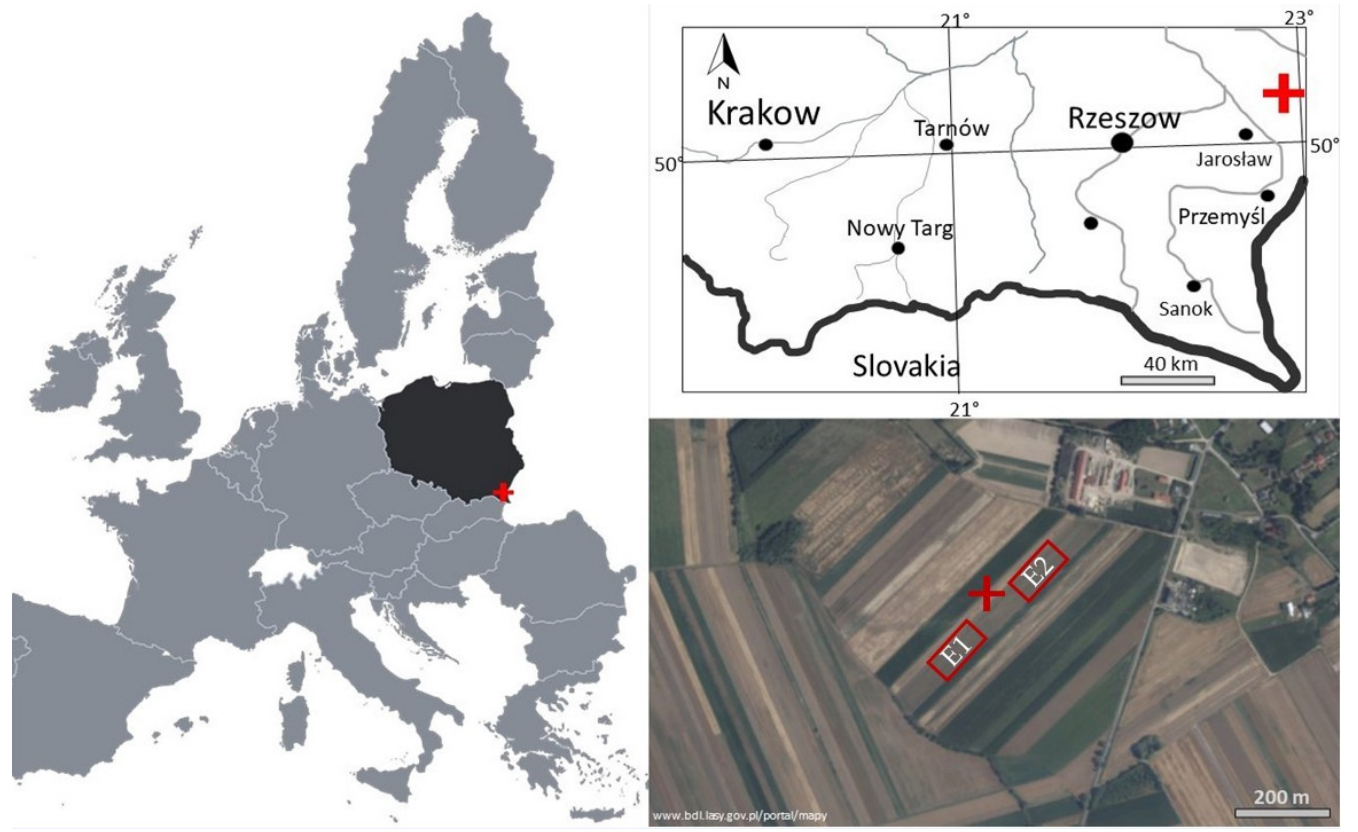

Figure 1. Location of the experimental field. E1—Gleyic Chernozem, E2—Haplic Luvisol [29].

Table 1. The amount of nutrients supplied to the soil with fertilisers $\left(\mathrm{kg} \mathrm{ha}^{-1} \mathrm{year}^{-1}\right)$.

\begin{tabular}{|c|c|c|c|c|c|c|c|}
\hline \multirow{2}{*}{$\begin{array}{l}\text { Amount of Pure Ingredient in } \\
\qquad \mathrm{kg} \mathrm{ha}^{-1} \text { year }^{-1}\end{array}$} & \multicolumn{7}{|c|}{ Experimental Objects } \\
\hline & Control & D1 & D2 & D3 & D4 & D5 & D6 \\
\hline $\mathrm{N}$ & 87.3 & 87.3 & 87.3 & 87.3 & 87.3 & 87.3 & 87.3 \\
\hline $\mathrm{P}$ & 19.8 & 19.8 & 27.3 & 34.9 & 42.4 & 50.0 & 57.5 \\
\hline $\mathrm{K}$ & - & 99.6 & 93.9 & 188 & 282 & 376 & 469 \\
\hline $\mathrm{Mg}$ & - & - & 23.0 & 45.0 & 69.1 & 90.0 & 115 \\
\hline $\mathrm{Ca}$ & - & - & 72.5 & 145 & 216 & 290 & 363 \\
\hline $\mathrm{Na}$ & - & - & 7.25 & 14.5 & 21.8 & 29.0 & 36.3 \\
\hline $\mathrm{Fe}$ & - & - & 21.8 & 43.5 & 65.3 & 87.0 & 109 \\
\hline $\mathrm{Mn}$ & - & - & 7.5 & 14.9 & 22.4 & 29.8 & 37.3 \\
\hline $\mathrm{Zn}$ & - & - & 2.10 & 4.20 & 6.30 & 8.40 & 10.6 \\
\hline $\mathrm{Cu}$ & - & - & 2.70 & 5.40 & 8.10 & 10.8 & 13.5 \\
\hline
\end{tabular}

Control—only N and P fertilization; D1-NPK mineral fertilization; D2-D6-N and P mineral fertilization + ash from biomass with different doses: $0.5,1.0,1.5,2.0,2.5 \mathrm{tha}^{-1}$, respectively.

\subsection{Soil Conditions}

The experiment was carried out on two types of soil: Gleyic Chernozem with a silty loam (SiL) and Haplic Luvisol with a silt (Si) particle size composition [30]. The $\mathrm{pH}$ values determined in $1 \mathrm{M} \mathrm{KCl}$ indicate a slightly acidic $\mathrm{pH}$ of Gleyic Chernozem $(1 \mathrm{KCl} 5.89)$ and an acidic $\mathrm{pH}$ of Haplic Luvisol (1KCl 5.15). The Haplic Luvisol soil had a low abundance of available forms of $\mathrm{P}\left(71.9 \mathrm{mg} \cdot \mathrm{kg}^{-1}\right)$, very high $\mathrm{Mg}\left(364 \mathrm{mg} \cdot \mathrm{kg}^{-1}\right)$ and medium abundance of $\mathrm{K}\left(128.5 \mathrm{mg} \cdot \mathrm{kg}^{-1}\right)$, Fe $\left(845 \mathrm{mg} \cdot \mathrm{kg}^{-1}\right), \mathrm{Mn}\left(147 \mathrm{mg} \cdot \mathrm{kg}^{-1}\right), \mathrm{Zn}\left(5.49 \mathrm{mg} \cdot \mathrm{kg}^{-1}\right)$ and $\mathrm{Cu}$ $\left(2.20 \mathrm{mg} \cdot \mathrm{kg}^{-1}\right)$ [30]. In turn, the abundance of available forms of $\mathrm{P}\left(2.56 \mathrm{mg} \cdot 100 \mathrm{~g}^{-1}\right)$ in Gleyic Chernozem soil was low, $\mathrm{K}\left(7.23 \mathrm{mg} \cdot 100 \mathrm{~g}^{-1}\right)$ was very low, $\mathrm{Mg}\left(13.51 \mathrm{mg} \cdot 100 \mathrm{~g}^{-1}\right)$ was 
high, and Fe (1439 mg.kg $\left.{ }^{-1}\right)$, and Mn (216 mg.kg $\left.{ }^{-1}\right), \mathrm{Zn}\left(11.39 \mathrm{mg} \cdot \mathrm{kg}^{-1}\right), \mathrm{Cu}\left(5.28 \mathrm{mg} \cdot \mathrm{kg}^{-1}\right)$ were average [31].

\subsection{Weather Conditions}

Weather conditions were given according to the records of the Experimental Station for Variety Testing in Skołoszów $\left(49^{\circ} 53^{\prime} \mathrm{N}, 22^{\circ} 44^{\prime} \mathrm{E}\right)$, Poland. The distance from the experimental field is approx. $15 \mathrm{~km}$. The weather in 2019-2021 was described on the basis of monthly rainfall, average air temperatures (Table 2) and Sielianinov's hydrothermal index (K) (Figure 2) described for Poland by Skowera et al. [32]. During the growing season of potato plants (April-September), the highest average air temperature in 2019-was $2.6^{\circ} \mathrm{C}$ higher than the average for 1980-2015, while in 2020 and 2021 it was lower than the multi-year average by 0.3 and $0.5^{\circ} \mathrm{C}$ (Table 2). The most intense rainfall was recorded in $2020-38.7 \%$ (153 mm) higher than the multi-year data. In 2019, the sum of precipitation in this period was $7.7 \%$ higher $(30 \mathrm{~mm})$ than the long-term data, while the sum of precipitation in 2021 was the closest to the multi-year average. Based on Sielianinov's hydrothermal index, the growing season in 2019 was defined as the optimal one, 2020 as humid, and 2021 as relatively humid (Figure 2). The meteorological conditions in each month were variable. Compared to the long-term data, the driest months were June and September 2019, while May 2020 and April 2021 were extremely humid and September 2020 and 2021 were very humid.

Table 2. Course of weather conditions during potato growing season (2019-2021).

\begin{tabular}{|c|c|c|c|c|c|c|c|}
\hline \multirow{2}{*}{ Years } & \multicolumn{6}{|c|}{ Months } & \multirow{2}{*}{$\begin{array}{c}\text { Period } \\
\text { Apr.-Sep. }\end{array}$} \\
\hline & Apr. & May & Jun. & Jul. & Aug. & Sep. & \\
\hline \multicolumn{7}{|c|}{ Rainfall (mm) } & Sum \\
\hline 2019 & 46.7 & 157 & 25.4 & 60.2 & 102 & 33.7 & 427 \\
\hline 2020 & 17.5 & 123 & 125 & 85.7 & 89.2 & 109 & 549 \\
\hline 2021 & 46.5 & 49.8 & 57.4 & 65.7 & 93.1 & 84.1 & 397 \\
\hline Mean for 1980-2015 & 42.1 & 67.5 & 75.1 & 90.4 & 58.8 & 62.1 & 396 \\
\hline \multicolumn{7}{|c|}{ Air Temperature $\left({ }^{\circ} \mathrm{C}\right)$} & Mean \\
\hline 2019 & 10.4 & 13.4 & 20.8 & 19.0 & 20.3 & 16.1 & 16.7 \\
\hline 2020 & 6.90 & 9.70 & 17.4 & 18.1 & 17.9 & 13.1 & 13.9 \\
\hline 2021 & 4.90 & 11.6 & 17.8 & 20.2 & 16.4 & 10.9 & 13.6 \\
\hline Mean for 1980-2015 & 8.80 & 13.0 & 15.2 & 17.5 & 17.2 & 13.0 & 14.1 \\
\hline
\end{tabular}

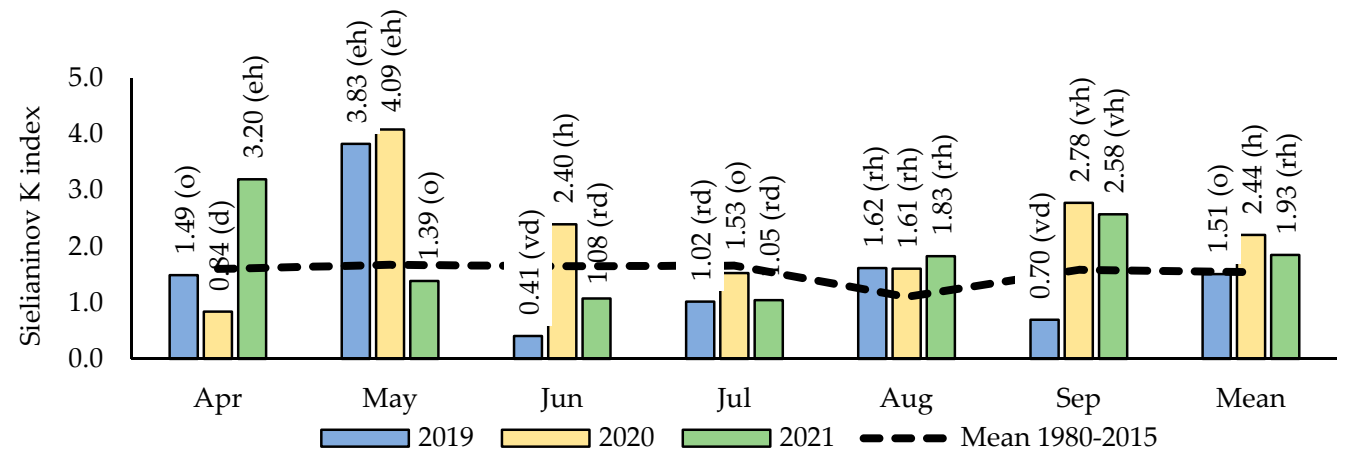

Figure 2. The hydrothermal index $(\mathrm{K})$ during the growing season of potato Sielianinov index $(\mathrm{K})$ : $\mathrm{K} \leq 0.4$ extremely dry (ed), $0.4<\mathrm{K} \leq 0.7$ very dry (vd), $0.7<\mathrm{K} \leq 1.0$ dry (d), $1.0<\mathrm{K} \leq 1.3$ relatively dry (rd), $1.3<\mathrm{K} \leq 1.6$ optimal (o), $1.6<\mathrm{K} \leq 2.0$ relatively humid (rh), $2.0<\mathrm{K} \leq 2.5$ humid (h), $2.5<\mathrm{K} \leq 3.0$ very humid (vh), and $\mathrm{K}>3.0$ extremely humid (eh). 


\subsection{Preparation of Samples for Strength Tests and Evaluation of the Morphological Features of Potato Tubers}

The potato tubers used for testing mechanical properties were taken immediately after harvest on the following dates: 26 September 2019, 25 September 2020 and 30 September 2021. The total tuber yield for each plot $\left(\mathrm{t} \cdot \mathrm{ha}^{-1}\right)$ was determined at the time of harvest. Then, for each variant of the experiment, 30 potato tubers were randomly collected without visible external damage to the peel and next they were transported to the laboratory, where they were washed. Then the tubers were measured (length, width and thickness-tolerance $0.01 \mathrm{~mm}$ ) and weighed (tolerance $0.1 \mathrm{~g}$ ). Tuber length $(L)$ was defined as the distance measured along the stolon-tip axis, tuber width $(W)$ as the length of the transverse axis, perpendicular to the longitudinal axis measured at the centre point along the length of the tuber, and the thickness of the tuber $(D)$ as the smaller dimension of the largest cross-section. Then, the sphericity factor (sphericity) $\varphi(\%)$, as well as the flattening factor (Wc) and the elongation factor (Wa), were calculated. Wc is expressed as the quotient of the width $(W)$ and thickness of the tuber $(D)$, while Wa is the quotient of its length $(L)$ and width (W) $[33,34]$.

Sphericity of tubers was calculated using the formula Equation (1):

$$
\varphi=\frac{(L W T)^{\frac{1}{3}}}{L} 100 \%
$$

where:

$$
\begin{aligned}
& \varphi \text {-sphericity (\%), } \\
& L \text {-length (mm), } \\
& W \text {-width (mm), } \\
& T \text {-thickness (mm). }
\end{aligned}
$$

\subsection{Measurement of Mechanical Properties}

The resistance of individual tubers to mechanical damage was determined under quasi-static loads using a Zwick/Roell Z010 testing machine (ZwickRoell GmbH \& Co. KG, Ulm, Germany) and a punch with a diameter of $\varphi=6 \mathrm{~mm}$. This machine consists of a base, a measuring head with a transducer equipped with a strain gauge element and a movable beam of a digital reader. During the measurement, the head transmits a signal corresponding to the puncture strength to the digital reader. The tests of mechanical properties were carried out with the set parameters: initial force $(\mathrm{Fv})=2 \mathrm{~N}$, speed of approach and return of the measuring beam equipped with a digital reader $(\mathrm{V} 1)=40 \mathrm{~mm} \mathrm{~min}^{-1}$, speed of the measuring beam equipped with a digital sensor during the measurement $(\mathrm{V} 2)=\mathrm{mm} \cdot \mathrm{min}^{-1}$. The research was carried out on whole potato tubers $(n=30)$ in the central part of the tuber. The following parameters indicating the resistance of tubers to mechanical damage were analysed: maximum peel and flesh puncture $\mathrm{F}_{\mathrm{D}}(\mathrm{N})$, maximum deformation Dmax (mm) at the moment of fracture and the destructive energy $E_{D}$ needed to destroy the sample $(\mathrm{J})$. The relative deformation $\mathrm{D}_{\mathrm{R}}(\%)$ was calculated as the ratio of the maximum deformation Dmax and tuber thickness $(T)$ according to the following formula Equation (2):

$$
\mathrm{D}_{\mathrm{R}}=\frac{D_{\max }}{T} 100 \%
$$

where:

$\mathrm{D}_{\mathrm{R}}$-relative deformation (\%),

$D_{\text {max }}$ - maximum deformation (mm),

$T$-thickness (mm). 


\subsection{Statistical Analyses}

Statistical analysis was performed using the TIBCO Statistica 13.3.0 software (TIBCO Software Inc., Palo Alto, CA, USA). Two-way analysis of variance (ANOVA) of the experiment was performed in a randomised block design and data analysis was carried out in a hierarchical-cross design. In order to determine and verify the relationship, Tukey's post-hoc range test was performed at the significance level of $5 \%$.

\section{Results}

Based on the statistical analysis of the data obtained in the experiment, it was shown that the soil type, different fertiliser treatments and the years of research had a significant impact on the potato tuber yield (Figure 3). On average over the years of research, the yield of the tuber in Gleyic Chernozem soil was higher by $10.9 \%\left(3.1 \mathrm{t} \cdot \mathrm{ha}^{-1}\right)$ compared to the yield obtained for tubers in Haplic Luvisol soil. Considering both types of soil, the highest yield was obtained in 2021, while in 2019 the yield of tubers in the Gleyic Chernozem soil was significantly lower than in the Haplic Luvisol, but an inverse relationship was noted in 2021, while in 2020 no significant differences in the level of potato yield were found. In 2021 the yield of tubers in the Gleyic Chernozem soil was higher than in 2019 and 2020 by 25.4 and $26.1 \mathrm{t} \cdot \mathrm{ha}^{-1}$ (51.8 and 53.1\%), respectively, and in the Haplic Luvisol soil by 6.7 and $11.2 \mathrm{t} \cdot \mathrm{ha}^{-1}$, respectively (19.4 and $32.1 \%$ ).

Considering both types of soil, fertilising with ash from biomass combustion had a positive effect on potato yield. On average, over the years of research, doses of ash D4 and D3 were the most favourable in the Gleyic Chernozem soil, under which the tuber yield increased significantly compared to the control plot by 31.7 and $30.4 \%$ (8.4 and $\left.8.1 \mathrm{t} \cdot \mathrm{ha}^{-1}\right)$, respectively, and compared to conventional mineral fertiliser D1, it increased by 11.9 and $10.7 \%$ (13.4 and $3.7 \mathrm{t} \cdot \mathrm{ha}^{-1}$ ) respectively. For Haplic Luvisol soil, the highest yield, significantly so, was obtained for the D4 variant, higher than in the control plot and D1 mineral fertiliser plot by 51.0 and $12.1 \%$, respectively $\left(11.2\right.$ and $\left.3.6 \mathrm{t} \cdot \mathrm{ha}^{-1}\right)$. For both types of soil, a further increase in doses of biomass ash resulted in a decrease in the potato tuber yield.

The experimental factors significantly influenced the morphological features of potato tubers (Table 3). The soil type had a significant impact on weight, length and width per tuber, but it did not significantly modify the thickness of the tuber. Potato tubers obtained from Gleyic Chernozem soil had an average weight greater by $27.9 \%(25.9 \mathrm{~g})$, they were longer by $6.7 \mathrm{~mm}$ and wider by $5.5 \mathrm{~mm}$ compared to tubers obtained from Haplic Luvisol soil. Differences in the fertilisers applied to potatoes determined the weight of tubers and their dimensions. On average, in relation to fertiliser application, the tubers with the smallest weight, as well as length, width and thickness, were obtained from the control plots, and the use of conventional mineral fertiliser and ash from biomass combustion increased the value of these features. Regardless of the soil type, the tubers with the highest mass were obtained after using D3, D4 and D5 fertiliser treatments, which was higher than in the case of the control plots by 32.5, 29.6 and $27.1 \mathrm{~g}(55.2,50.2$ and $46.1 \%)$, respectively, and in the case of conventional mineral fertiliser (D1) by 11.6, 8.7 and $6.3 \mathrm{~g}$ $(14.6,10.9$ and $7.9 \%)$. The application of the highest dose of biomass ash (D6) caused a decrease in the width and thickness to a level not significantly different from the control plots. The experiment showed a significant interaction between soil type and fertiliser treatment. The tubers of plants grown on Gleyic Chernozem and fertilised with D3 and D4 had the highest weight, and the lowest weight was obtained on Haplic Luvisol soil in the control variant and when the fertiliser treatment D6 was used. The use of classic mineral fertiliser as well as fertilising with ash from biomass combustion had a positive effect on the dimensions of the tubers examined, regardless of the type of soil. Soil type, fertiliser treatment and the interaction of these factors did not have a significant effect on sphericity, flattening factor $\left(\mathrm{W}_{\mathrm{c}}\right)$ and elongation factor $\left(\mathrm{W}_{\mathrm{a}}\right)$. Morphological features of analyzed potato tubers according to soil type and fertilization in the study years 2019-2021 are presented in Table S2. 

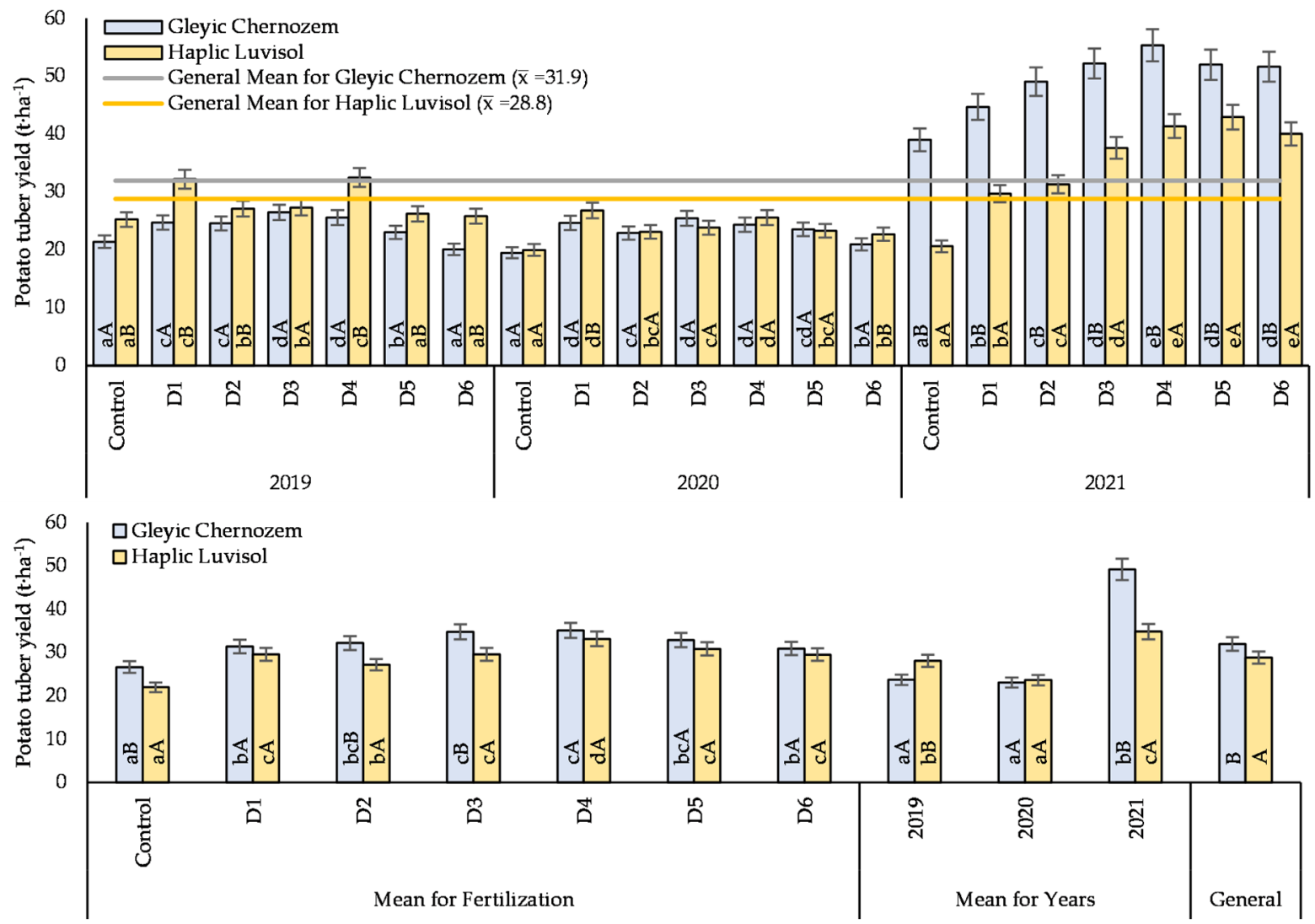

Figure 3. Average potato tuber yield $\left(\mathrm{t} \cdot \mathrm{ha}^{-1}\right)$ depending on the type of soil, fertiliser applied and year of research. Statistical data are expressed as mean \pm SD values. Different letters show significant differences $(p<0.05)$ according to Tukey's range test. Capital letters mean differences between particular types of soil, small letters mean differences between particular doses of fertiliser.

Table 3. Morphological features of the potato tubers examined depending on soil type, fertiliser treatment and year of research-mean for factors and interaction soil type $\mathrm{x}$ fertiliser treatment.

\begin{tabular}{|c|c|c|c|c|c|c|c|c|}
\hline & \multirow{2}{*}{ Variables } & \multirow{2}{*}{$\begin{array}{l}\text { Weight of } \\
1 \text { Tuber (g) }\end{array}$} & \multicolumn{3}{|c|}{ Dimensions (mm) } & \multirow{2}{*}{$\underset{(\%)}{\text { Sphericity }}$} & \multirow{2}{*}{$\begin{array}{l}\text { Flattening } \\
\text { Factor } W_{c}\end{array}$} & \multirow{2}{*}{$\begin{array}{l}\text { Elongation } \\
\text { Factor } W_{a}\end{array}$} \\
\hline & & & Length & Width & Thickness & & & \\
\hline \multicolumn{9}{|c|}{ Interaction soil type $\times$ fertilisation } \\
\hline \multirow{7}{*}{ 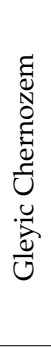 } & Control & $68.7^{\mathrm{ab}} \pm 23.9$ & $55.8^{\mathrm{abc}} \pm 9.4$ & $45.1^{\mathrm{ab}} \pm 5.1$ & $39.7^{\text {abcd }} \pm 5.0$ & $83.6 \pm 4.8$ & $1.14 \pm 0.05$ & $1.40 \pm 0.10$ \\
\hline & D1 & $86.7^{\mathrm{bcd}} \pm 23.8$ & $61.9^{b c} \pm 10.4$ & $49.2^{\mathrm{bcd}} \pm 4.0$ & $43.0^{\text {cde }} \pm 4.0$ & $82.8 \pm 7.0$ & $1.14 \pm 0.04$ & $1.44 \pm 0.18$ \\
\hline & D2 & $87.7^{\text {bcd }} \pm 33.8$ & $59.4^{\mathrm{abc}} \pm 11.2$ & $49.2^{\mathrm{bcd}} \pm 8.0$ & $43.1^{\text {cde }} \pm 6.8$ & $85.0 \pm 7.4$ & $1.14 \pm 0.06$ & $1.38 \pm 0.16$ \\
\hline & D3 & $111.6^{\mathrm{d}} \pm 55.1$ & $65.9^{c} \pm 13.2$ & $52.9^{\mathrm{cd}} \pm 8.6$ & $46.4^{\mathrm{e}} \pm 8.0$ & $83.2 \pm 5.2$ & $1.14 \pm 0.04$ & $1.42 \pm 0.12$ \\
\hline & D4 & $103.3^{\mathrm{d}} \pm 44.2$ & $64.8^{c} \pm 15.8$ & $50.0^{\mathrm{bcd}} \pm 8.3$ & $43.5^{\text {cde }} \pm 7.1$ & $81.4 \pm 6.5$ & $1.15 \pm 0.04$ & $1.47 \pm 0.17$ \\
\hline & D5 & $97.6^{\mathrm{cd}} \pm 33.7$ & $66.4^{c} \pm 16.4$ & $53.8^{\mathrm{d}} \pm 14.9$ & $44.4^{\text {de }} \pm 6.2$ & $82.1 \pm 5.7$ & $1.21 \pm 0.23$ & $1.49 \pm 0.23$ \\
\hline & D6 & $95.5^{\mathrm{bcd}} \pm 34.5$ & $66.5^{c} \pm 17.1$ & $49.8^{\mathrm{bcd}} \pm 5.7$ & $42.8^{\text {cde }} \pm 5.2$ & $79.7 \pm 7.0$ & $1.17 \pm 0.04$ & $1.54 \pm 0.24$ \\
\hline \multirow{7}{*}{ 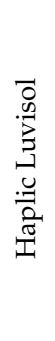 } & Control & $49.0^{\mathrm{a}} \pm 16.7$ & $48.2^{a} \pm 8.2$ & $39.2^{\mathrm{a}} \pm 4.8$ & $34.7^{\mathrm{a}} \pm 4.5$ & $84.2 \pm 5.7$ & $1.13 \pm 0.03$ & $1.39 \pm 0.14$ \\
\hline & D1 & $72.7^{\mathrm{abc}} \pm 17.1$ & $60.5^{b c} \pm 8.4$ & $45.6^{\mathrm{b}} \pm 3.6$ & $40.1^{\mathrm{bcd}} \pm 3.3$ & $79.8 \pm 6.0$ & $1.14 \pm 0.05$ & $1.51 \pm 0.18$ \\
\hline & D2 & $70.4^{\mathrm{abc}} \pm 14.3$ & $57.1^{\mathrm{abc}} \pm 4.3$ & $45.2^{\mathrm{ab}} \pm 5.2$ & $40.6^{\mathrm{bcd}} \pm 3.6$ & $82.6 \pm 6.0$ & $1.11 \pm 0.05$ & $1.42 \pm 0.15$ \\
\hline & D3 & $71.1^{\mathrm{abc}} \pm 22.1$ & $58.4^{\mathrm{abc}} \pm 7.3$ & $45.9^{\mathrm{abc}} \pm 6.1$ & $39.2^{\mathrm{abc}} \pm 4.8$ & $80.2 \pm 5.5$ & $1.16 \pm 0.04$ & $1.47 \pm 0.13$ \\
\hline & D4 & $73.5^{\mathrm{abc}} \pm 21.9$ & $57.8^{\mathrm{abc}} \pm 7.1$ & $45.7^{\mathrm{abc}} \pm 5.2$ & $40.9^{b c d} \pm 3.6$ & $82.8 \pm 6.7$ & $1.12 \pm 0.05$ & $1.42 \pm 0.16$ \\
\hline & D5 & $74.4^{\mathrm{abc}} \pm 22.6$ & $59.1^{\mathrm{abc}} \pm 8.6$ & $46.8^{\mathrm{bcd}} \pm 5.5$ & $40.6^{\mathrm{bcd}} \pm 4.6$ & $82.1 \pm 6.5$ & $1.15 \pm 0.06$ & $1.46 \pm 0.16$ \\
\hline & D6 & $58.3^{\mathrm{a}} \pm 12.3$ & $52.7^{\mathrm{ab}} \pm 6.8$ & $42.9^{\mathrm{ab}} \pm 4.0$ & $37.5^{\mathrm{ab}} \pm 3.3$ & $83.9 \pm 6.6$ & $1.14 \pm 0.05$ & $1.41 \pm 0.16$ \\
\hline
\end{tabular}


Table 3. Cont.

\begin{tabular}{|c|c|c|c|c|c|c|c|c|}
\hline & \multirow{2}{*}{ Variables } & \multirow{2}{*}{$\begin{array}{l}\text { Weight of } \\
1 \text { Tuber (g) }\end{array}$} & \multicolumn{3}{|c|}{ Dimensions (mm) } & \multirow{2}{*}{$\underset{(\%)}{\text { Sphericity }}$} & \multirow{2}{*}{$\begin{array}{l}\text { Flattening } \\
\text { Factor } W_{c}\end{array}$} & \multirow{2}{*}{$\begin{array}{l}\text { Elongation } \\
{\text { Factor } W_{a}}^{2}\end{array}$} \\
\hline & & & Length & Width & Thickness & & & \\
\hline \multicolumn{9}{|c|}{ Mean for factors } \\
\hline \multirow{2}{*}{ 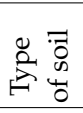 } & $\begin{array}{l}\text { Gleyic } \\
\text { hernozem }\end{array}$ & $93.0^{\mathrm{b}} \pm 37.9$ & $62.9^{b} \pm 13.7$ & $50.0^{\mathrm{b}} \pm 8.6$ & $43.3 \pm 6.2$ & $82.6 \pm 6.3$ & $1.16 \pm 0.10$ & $1.45 \pm 0.18$ \\
\hline & Haplic Luvisol & $67.1^{\mathrm{a}} \pm 20.0$ & $56.3^{\mathrm{a}} \pm 8.2$ & $44.5^{\mathrm{a}} \pm 5.4$ & $41.9 \pm 4.4$ & $82.2 \pm 6.1$ & $1.14 \pm 0.05$ & $1.44 \pm 0.15$ \\
\hline \multirow{7}{*}{ 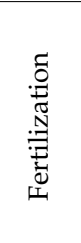 } & Control & $58.9^{\mathrm{a}} \pm 22.5$ & $52.0^{\mathrm{a}} \pm 9.5$ & $42.1^{\mathrm{a}} \pm 5.7$ & $37.2^{\mathrm{a}} \pm 5.3$ & $83.9 \pm 5.1$ & $1.13 \pm 0.04$ & $1.39 \pm 0.12$ \\
\hline & D1 & $79.7^{b} \pm 21.5$ & $61.2^{b} \pm 9.3$ & $47.4^{b} \pm 4.1$ & $41.6^{b} \pm 3.9$ & $81.3 \pm 6.6$ & $1.14 \pm 0.04$ & $1.47 \pm 0.18$ \\
\hline & D2 & $79.1^{b} \pm 26.8$ & $58.2^{\mathrm{ab}} \pm 8.3$ & $47.2^{b} \pm 6.9$ & $41.8^{\mathrm{b}} \pm 5.4$ & $83.8 \pm 6.7$ & $1.13 \pm 0.06$ & $1.40 \pm 0.15$ \\
\hline & D3 & $91.3^{c} \pm 46.0$ & $62.1^{\mathrm{b}} \pm 11.1$ & $49.4^{b} \pm 8.2$ & $42.8^{\mathrm{b}} \pm 7.4$ & $81.7 \pm 5.4$ & $1.15 \pm 0.04$ & $1.44 \pm 0.13$ \\
\hline & D4 & $88.4^{b c} \pm 37.4$ & $61.3^{b} \pm 12.5$ & $47.9^{b} \pm 7.1$ & $42.2^{b} \pm 5.6$ & $82.1 \pm 6.5$ & $1.13 \pm 0.05$ & $1.45 \pm 0.16$ \\
\hline & D5 & $86.0^{b c} \pm 30.5$ & $62.8^{b} \pm 13.3$ & $50.3^{b} \pm 11.5$ & $42.5^{b} \pm 5.7$ & $82.1 \pm 6.0$ & $1.18 \pm 0.17$ & $1.47 \pm 0.20$ \\
\hline & D6 & $76.9^{b} \pm 31.6$ & $59.6^{b} \pm 14.6$ & $46.4^{\mathrm{ab}} \pm 6.0$ & $40.2^{\mathrm{ab}} \pm 5.0$ & $81.8 \pm 7.0$ & $1.15 \pm 0.05$ & $1.47 \pm 0.21$ \\
\hline \multirow{3}{*}{ ્ֻરే } & 2019 & $61.1^{\mathrm{a}} \pm 18.3$ & $50.5^{\mathrm{a}} \pm 8.0$ & $44.3^{a} \pm 5.4$ & $37.6^{\mathrm{a}} \pm 4.4$ & $87.1^{c} \pm 3.9$ & $1.18^{b} \pm 0.04$ & $1.34^{\mathrm{a}} \pm 0.10$ \\
\hline & 2020 & $76.3^{b} \pm 30.0$ & $65.3^{b} \pm 11.4$ & $44.9^{\mathrm{a}} \pm 5.8$ & $40.9^{\mathrm{a}} \pm 5.2$ & $75.9^{a} \pm 3.9$ & $1.10^{\mathrm{a}} \pm 0.04$ & $1.59^{b} \pm 0.14$ \\
\hline & 2021 & $102.7^{\mathrm{c}} \pm 33.9$ & $63.0^{\mathrm{b}} \pm 9.7$ & $52.5^{b} \pm 8.5$ & $49.2^{b} \pm 5.1$ & $84.2^{b} \pm 4.1$ & $1.16^{\mathrm{b}} \pm 0.11$ & $1.39^{\mathrm{a}} \pm 0.14$ \\
\hline
\end{tabular}

Statistical data are expressed as mean \pm SD values. Different letters show significant differences $(p<0.05)$ according to Tukey's range test.

Regardless of the type of soil, fertiliser applied and year of research, the puncture force of the peel and flesh of potato tubers ranged from 56.2 to $71.7 \mathrm{~N}$ (Figure 4). Potatoes grown on Gleyic Chernozem soil required a significantly higher $\mathrm{F}_{\mathrm{D}}(3.3 \mathrm{~N})$ to pierce the peel and flesh than the tubers of plants grown on Haplic Luvisol soil. Tubers obtained in 2021 had the lowest $F_{D}$ on both types of soil. For Gleyic Chernozem soil, in 2021, tubers required significantly lower $\mathrm{F}_{\mathrm{D}}$ than in 2019 and 2020 by 6.5 and $6.7 \mathrm{~N}$, respectively, and for Haplic Luvisol soil by 6.9 and $7.2 \mathrm{~N}$, respectively. The parameter discussed was also influenced by differences in the fertiliser treatments of the potatoes. On average, as far as fertiliser treatment is concerned, tubers of plants fertilised with doses D4 and D3 required the highest FD for both types of soils. For the Gleyic Chernozem soil, in the case of fertiliser treatment with the doses D3 and D4, the value of the parameter examined was significantly higher compared to the control plot by 11.6 and $12.0 \%(6.0$ and $8.0 \mathrm{~N})$, respectively, and in the case of conventional mineral fertiliser (D1) it was higher by 4.5 and $6.5 \%$ (3.0 and $4.2 \mathrm{~N}$ ), respectively. The fertiliser variants of Haplic Luvisol had a more significant impact on $\mathrm{F}_{\mathrm{D}}$. The use of $\mathrm{D} 3$ and $\mathrm{D} 4$ significantly increased the parameter examined compared to the control plot by 20.7 and $21.4 \%(11.6$ and $12.0 \mathrm{~N})$ and for mineral fertiliser by 8.8 and $9.5 \%$ ( 5.5 and $5.9 \%$, respectively) ( 5.5 and $5.9 \mathrm{~N}$ ). For both types of soil, a further increase in ash doses caused a decrease in $\mathrm{F}_{\mathrm{D}}$.

For Gleyic Chernozem and Haplic Luvisol soil, the $F_{D}$ value was the highest of the D3 and D4 fertiliser variants in 2019 and 2020, and this difference was significant. Plants reacted slightly differently to fertiliser variants in 2021. For Gleyic Chernozem soil, the highest FD was required by tubers in variants D4 and D5, and in the case of Haplic Luvisol soil, the value of this parameter did not differ significantly between variants when the plots were fertilised with biomass ash (D3-D6). 

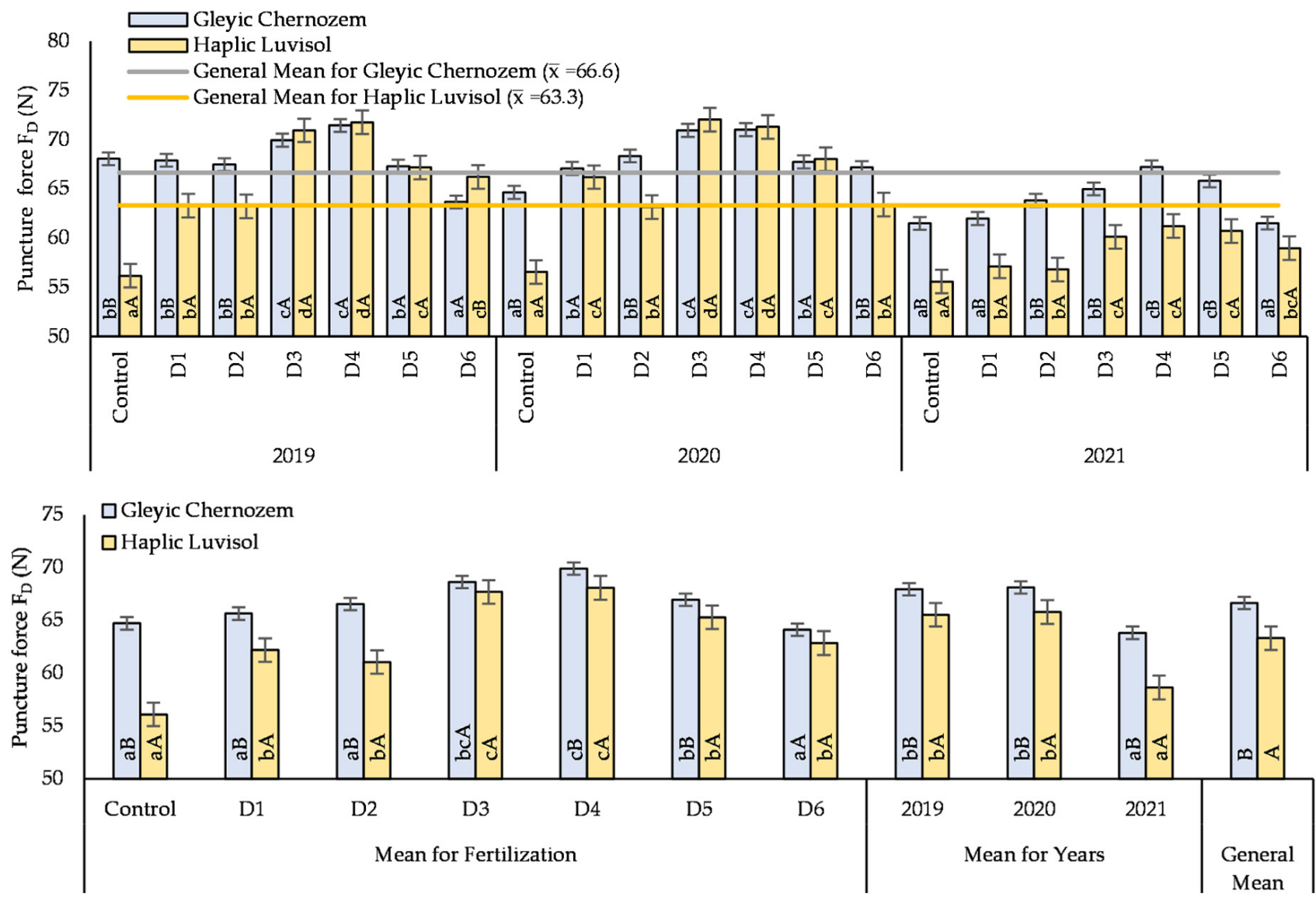

Figure 4. Average values of the puncture force of potato tuber peels and flesh $\mathrm{F}_{\mathrm{D}}(\mathrm{N})$ depending on the type of soil, fertiliser applied and year of research. Statistical data are expressed as mean \pm SD values. Different letters show significant differences $(p<0.05)$ according to Tukey's range test. Capital letters mean differences between particular types of soil, small letters mean differences between particular doses of fertiliser.

Regardless of the fertiliser used and the years of research, tubers of plants grown on Haplic Luvisol soil underwent stronger deformation than tubers obtained from plots where plants were grown on Gleyic Chernozem soil (Figure 5). The weather conditions in the years of the study were also a factor influencing the $D_{R}$. In 2019, the tubers from both types of soil exhibited significantly higher susceptibility to deformation compared to tubers that were planted on Gleyic Chernozem soil and harvested in 2021 and 2020. On average, for the Gleyic Chernozem plots treated with fertiliser, the significantly highest $D_{R}$ values were obtained as a result of D3 and D4 fertiliser treatments (7.61 and 7.57\%, respectively), and significantly higher than for the control plot (by 0.22 and $0.19 \%$ ), respectively and the fertiliser treatment with the highest dose of ash from biomass combustion (by 0.21 and $0.18 \%$ ), respectively, where the lowest values of this parameter were obtained. Similar relationships were found with Haplic Luvisol soil, where the tubers in the D3 and D4 variants had the strongest $D_{R}$, and the lowest value of $D_{R}$ was obtained for tubers from the control plot. 

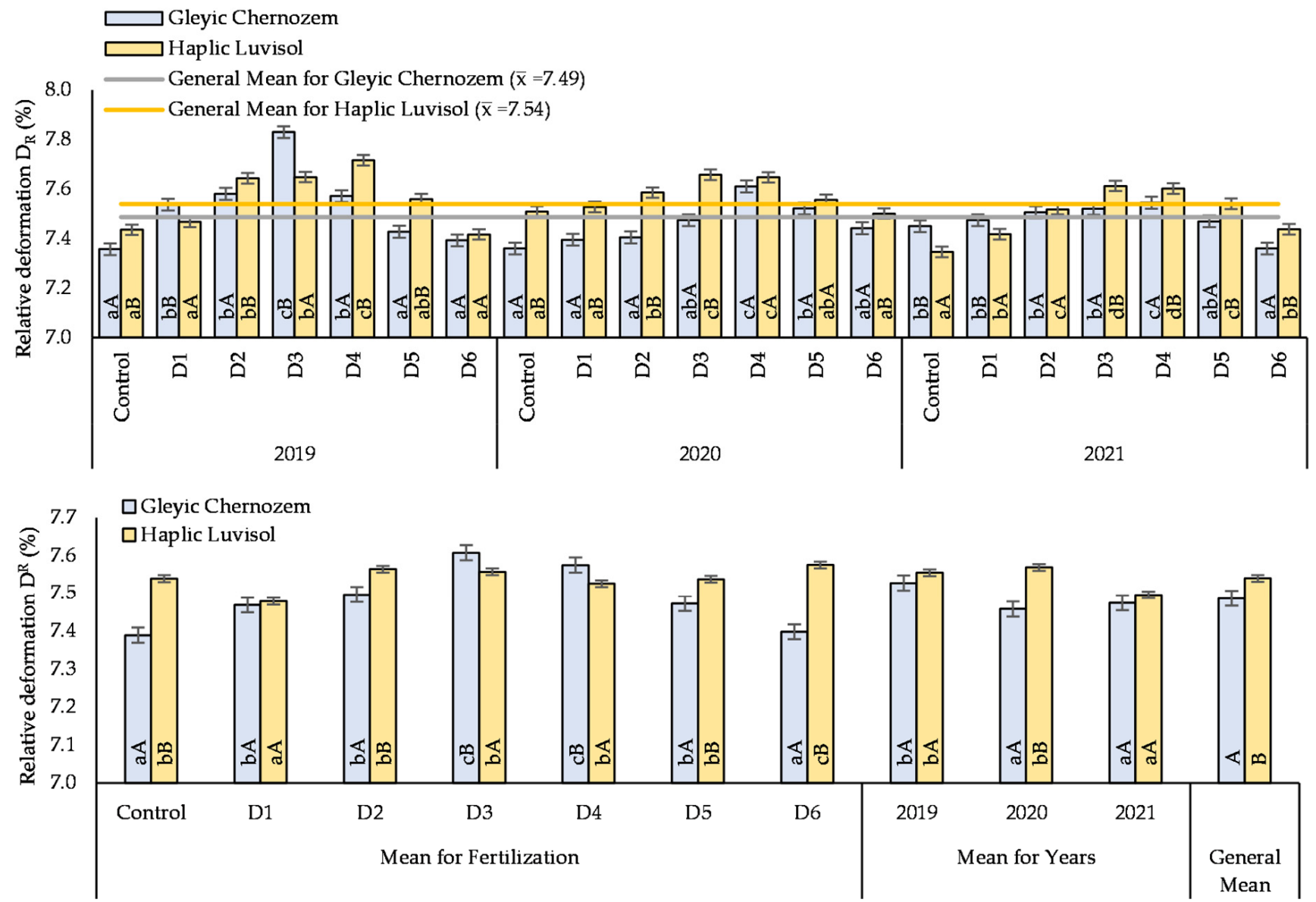

Figure 5. Average values of the relative deformation $D_{R}(\%)$ depending on the type of soil, fertiliser applied and year of research. Statistical data are expressed as mean $\pm \mathrm{SD}$ values. Different letters show significant differences $(p<0.05)$ according to Tukey's range test. Capital letters mean differences between particular types of soil, small letters mean differences between particular doses of fertiliser.

On average, over the years of research, potato tubers grown on Gleyic Chernozem soil, required $10.8 \%(18.3 \mathrm{~mJ})$ higher breakthrough energy $\left(\mathrm{E}_{\mathrm{D}}\right)$ than tubers of plants grown on Haplic Luvisol soil (Figure 6). Such a relationship was observed in each year of the study. On both types of soil, the lowest $E_{D}$ was required for tubers harvested in 2021, lower $E_{D}$ than that in 2019 and 2020. On Gleyic Chernozem, this was by 10.5 and $13.8 \%$, respectively (18.3 and $24.1 \mathrm{~mJ}$ ), and on Haplic Luvisol by 16.8 and $25.2 \%$, respectively (25.1 and $37.6 \mathrm{~mJ}$ ). On average, for fertiliser treatments of Gleyic Chernozem soil, the highest $E_{D}$ was required by the sample of tubers of plants fertilised with doses D4 and D5, significantly higher $\mathrm{E}_{\mathrm{D}}$ than in the control plot by 21.7 and $17.2 \%$ (37.1 and $29.4 \mathrm{~mJ}$ ), respectively. For Haplic Luvisol soil, the significantly highest $\mathrm{E}_{\mathrm{D}}$ values were obtained in the case of the D4 fertiliser treatment, which was $29.3 \%$ (43.8 mJ) higher than for the control sample. Further increasing the doses of ash from biomass combustion decreased the value of the $\mathrm{E}_{\mathrm{D}}$ parameter. 

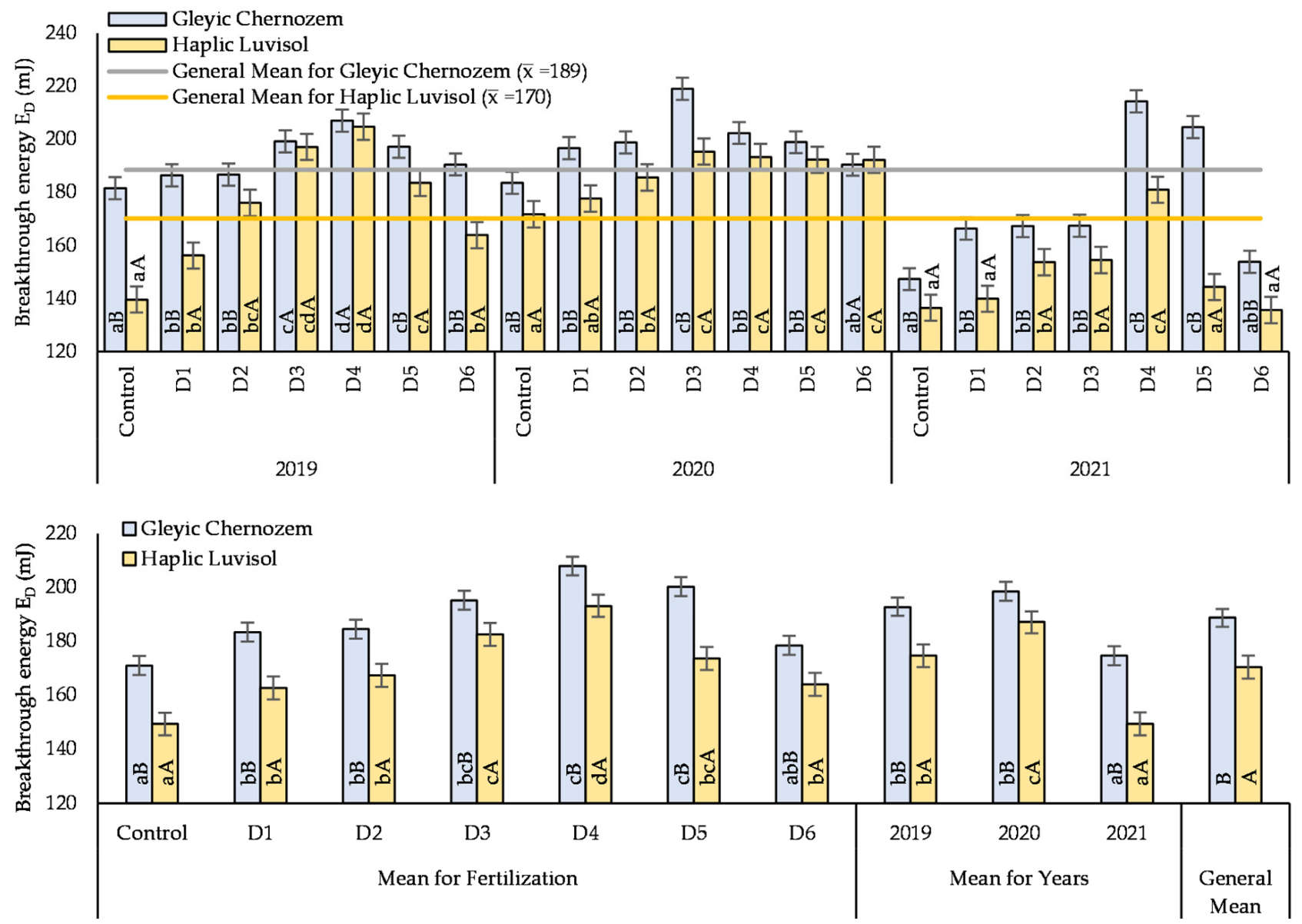

Figure 6. Average values of the breakthrough energy $E_{D}(m J)$ depending on the type of soil, fertiliser applied and year of research. Statistical data are expressed as mean \pm SD values. Different letters show significant differences $(p<0.05)$ according to Tukey's range test. Capital letters mean differences between particular types of soil, small letters mean differences between particular doses of fertiliser.

\section{Discussion}

Declining areas of fertile soil, water scarcity, changing weather conditions combined with increasing urbanisation, food insecurity and climate change have put severe pressure on the agricultural sector [35,36]. Therefore, there is more and more interest in finding improved or new alternatives to meet the growing demand for food and feedstuffs [37]. The quality of agricultural raw materials depends on their chemical and physical properties, as well as parameters linked to their processing. Potato is a very attractive crop in agricultural production systems because it combines a high yield potential with high nutritional value. However, while countries with high-input farming techniques can achieve average potato yields above $45 \mathrm{t} \mathrm{ha}^{-1}$, average yields in most other countries are much lower, making the world average potato yield $20 \mathrm{tha}^{-1}$ [38]. Larkin [39] points out that sustainable development of crop production systems depends on many factors, and the most important is the productivity of crops, usually measured by yield. Crop yields are the end result, but many aspects of crop development and growth may be involved or responsible for crop yield and quality [40]. In the authors' own research, the average yield of potato tubers depended on the type of soil and was of the order of $31.9 \mathrm{t} \mathrm{ha}^{-1}$ for the Gleyic Chernozem soil and $28.8 \mathrm{t} \mathrm{ha}^{-1}$ for the Haplic Luvisol soil. The potato tuber yield obtained also depended on the weather conditions in the individual years of research and the fertiliser treatment applied. On both types of soils, fertilising with ash from biomass combustion had a positive effect on potato yield. On average, during the years of research, for the Gleyic Chernozem soil the doses of ash D4 and D3 turned out to be the most favourable, as 
a result of which the tuber yield increased significantly compared to the control plot and conventional D1 mineral fertiliser. For the Haplic Luvisol soil, the significantly highest yield was obtained in the D4 variant, higher compared to the control plot and D1 mineral fertiliser treatment. Regardless of the soil type, a further increase of biomass ash doses decreased the yield of potato tubers. The application of soil $\mathrm{K}$ fertiliser in the form of ash from biomass combustion had a positive effect on the tuber yield obtained in comparison with the control plot. $\mathrm{K}$ is known to be an essential nutrient for plant growth [41]. The main functions of $\mathrm{K}$ in plants are the control of enzyme activity, cation-anionic homeostasis and membrane polarisation. They are based on its osmotic nature, therefore it is needed for cell proliferation, regulation of turgor and movement of the stomata [42-45]. As the K content in wood ash can even reach $50 \%$ by weight (converted into $\mathrm{K}_{2} \mathrm{O}$ ), this type of ash is used as a $\mathrm{K}$ source for the production of fertilisers [11]. Wood ash is poor in nitrogen, therefore it cannot be used as a general fertiliser [13], but it can be treated as a special correction providing alkaline earth metals that are able to neutralise the acidity of the soil.

With the growing demand for high-quality agricultural raw materials, it is important to develop methods for the rapid monitoring of post-harvest quality [46,47]. Potato tubers should be of the best quality and regularity of shape in order to avoid many losses during processing [48-50]. According to Zhanga et al. [51] external appearance is the most important attribute of the sensory quality of agricultural products. Assessment of the size and shape of the tubers is an important step in the classification of tubers during the post-harvest process. The big difficulty is that tubers, as biological material, are easily damaged and their reaction to external factors is random. Differences in the size and shape spectrum of potatoes and their vulnerability to damage make potato crops difficult to handle and grade [52]. It was found that the experimental factors significantly influenced the morphological features of potato tubers and their uniformity within the test sample. The soil type had a significant effect on the weight, length and width of a tuber, but did not significantly modify its thickness. Potato tubers obtained from Gleyic Chernozem soil had greater weight and were longer and wider than tubers developed by plants on Haplic Luvisol soil. For the Gleyic Chernozem soil, the use of conventional mineral fertiliser, as well as ash from biomass combustion, increased the value of these features to the D3 level and to D5 for the Haplic Luvisol soil. Both fertiliser and soil type had no significant effect on sphericity, $\mathrm{W}_{\mathrm{c}}$ and $\mathrm{W}_{\mathrm{a}}$. Consumers and food processors prefer regular sized potatoes because irregular sizes can cause undesirable effects during food processing, such as high losses on peeling [53]. Mohd Ali et al. [54] emphasise that early detection of surface defects can prevent or hinder the further spreading of the damage throughout the product. In turn, Thybo et al. [55] believe that texture is the most important character of potato tubers assessed by consumers. The structural properties of plant tissues, like all horticultural products, affect the quality of potato tubers. Mechanical damage is the result of many factors that can be divided into: biological (related to the genetic characteristics of the cultivar), environmental (resulting from climatic, soil and agro-technical conditions) and technical (determined by the design features of the machines). Due to the nature of the damage, damage is divided into external, manifested as damage of the peel and flesh, and internal, when the skin remains intact and the flesh of the tuber is damaged. A damaged texture will deteriorate the physical condition, make measurement difficult and increase the likelihood of rejecting a fresh tuber $[21,56]$. Quasi-static mechanical tests are widely used to obtain objective data on the mechanical and textural properties of vegetables. In the experiment, potato tubers planted on Gleyic Chernozem soil required significantly higher $\mathrm{F}_{\mathrm{D}}$ than tubers of plants grown on Haplic Luvisol soil. The range of fertiliser treatments of potatoes also influenced the value of $F_{D}$. On both types of soils, the highest $F_{D}$ was required by tubers of plants fertilised with D4 and D3 doses, and a further increase in the dose of ash caused a decrease in $\mathrm{F}_{\mathrm{D}}$. A similar relationship was noted for $\mathrm{E}_{\mathrm{D}}$. Tubers of plants grown on Haplic Luvisol soil underwent a stronger $D_{R}$ than on Gleyic Chernozem soil. 


\section{Conclusions}

The research attempted to determine the effect of soil fertiliser treatment with ash from biomass combustion on selected physical properties of potato tubers in order to increase their resistance to mechanical damage. It was found that the use of ash-based fertiliser significantly increased the tolerance of the test potato tubers to mechanical damage under quasi-static loads, regardless of the type of soil on which the cultivation was carried out, which indicates the possibility of universal application of fertilisers based on biomass ash in potato cultivation. The highest values of the mechanical parameters examined were obtained for potato tubers from plots where D3 and D4 fertiliser treatment was applied (188 and $282 \mathrm{~kg} \cdot \mathrm{ha}^{-1} \mathrm{~K}$, respectively), which corresponds to the tuber yield obtained. The data obtained provide knowledge on the mechanical properties of potato tubers if the fertiliser with biomass ash is applied. This knowledge can be used in the design of fertiliser treatments and in determining the parameters for the harvesting, storage and processing of tubers. The data presented also indicate that fertilisers based on biomass ash are an alternative to conventional mineral fertilisers and can be used in the development of fertiliser treatment plans for sustainable agriculture and solve the problem of landfilling waste from plant biomass combustion.

Supplementary Materials: The following supporting information can be downloaded at: https: / / www.mdpi.com/article/10.3390/agronomy12020379/s1, Table S1: Mineral composition of ash from biomass combustion ( $\mathrm{mg} \cdot \mathrm{kg}^{-1}$ ); Table S2: Morphological features of analysed potato tubers according to soil type and fertilization in the study years 2019-2021.

Author Contributions: Conceptualization, E.S.-K., D.M. and M.S.; methodology, E.S.-K. and D.M.; formal analysis, D.M.; investigation, E.S.-K., D.M., M.S., R.P. and J.G.; resources, E.S.-K.; writingoriginal draft preparation, E.S.-K. and D.M.; writing-review and editing, M.S.; visualization, E.S.-K. and D.M. All authors have read and agreed to the published version of the manuscript.

Funding: The project is financed by the program of the Minister of Science and Higher Education named "Regional Initiative of Excellence" in the years 2019-2022, project number 026/RID/2018/19, the amount of financing PLN 9542500.00 and from financial resources of the Ministry of Science and Higher Education for scientific activities of the Institute of Agricultural Sciences, Land Management and Environmental Protection, University of Rzeszow.

Institutional Review Board Statement: Not applicable.

Informed Consent Statement: Not applicable.

Data Availability Statement: The data presented in this study are available in this article.

Conflicts of Interest: The authors declare no conflict of interest.

\section{References}

1. Vaitkevičienè, N. A comparative study on proximate and mineral composition of coloured potato peel and flesh. J. Sci. Food Agric. 2019, 99, 6227-6233. [CrossRef] [PubMed]

2. Haverkort, A.; De Ruijter, F.; Van Evert, F.; Conijn, J.; Rutgers, B. Worldwide sustainability hotspots in potato cultivation. Identification and mapping. Potato Res. 2013, 56, 343-353. [CrossRef]

3. Albiski, F.; Najla, S.; Sanoubar, R.; Alkabani, N.; Murshed, R. In Vitro Screening of Potato Lines for Drought Tolerance. Physiol. Mol. Biol. Plants 2012, 18, 315-321. [CrossRef] [PubMed]

4. Birch, P.R.J.; Bryan, G.J.; Fenton, B.; Gilroy, E.M.; Hein, I.; Jones, J.T.; Prashar, A.; Taylor, M.A.; Torrance, L.; Toth, I.K. Crops that feed the world 8: Potato: Are the trends of increased global production sustainable? Food Secur. 2012, 4, 477-508. [CrossRef]

5. Mullins, E.; Milbourne, D.; Petti, C.; Doyle-Prestwich, B.M.; Meade, C. Potato in the age of biotechnology. Trends Plant Sci. 2006, 11, 254-260. [CrossRef]

6. Food and Agriculture Organization Corporate Statistical Database. Available online: http://www.fao.org/faostat/en/\#data/QC (accessed on 11 June 2021).

7. Samaniego, I.; Espin, S.; Cuesta, X.; Arias, V.; Rubio, A.; Llerena, W.; Angós, I.; Carrillo, W. Analysis of environmental conditions effect in the phytochemical composition of potato (Solanum tuberosum) Cultivars. Plants 2020, 9, 815. [CrossRef]

8. Calliope, S.R.; Lobo, M.O.; Sammán, N.C. Biodiversity of Andean potatoes: Morphological, nutritional and functional characterization. Food Chem. 2018, 238, 42-50. [CrossRef] 
9. Karltun, E.; Saarsalmi, A.; Ingerslev, M.; Mandre, M.; Andersson, S.; Gaitnieks, T.; Ozolinčius, R.; Varnagiryte-Kabasinskiene, I. Wood Ash Recycling_Possibilities and Risks. In Sustain. Use for Biomass Energy. Managing Forest Ecosystems; Röser, D., Asikainen, A., Raulund-Rasmussen, K., Stupak, I., Röser, D., Asikainen, A., Raulund-Rasmussen, K., Stupak, I., Eds.; Springer: Dordrecht, The Netherlands, 2008; Volume 12, pp. 79-108. [CrossRef]

10. Huotaria, N.; Tillman-Sutela, E.; Moilanen, M.; Laiho, R. Recycling of ash-For the good of the environment? For. Ecol. Manag. 2015, 348, 226-240. [CrossRef]

11. Maschowski, C.; Zangna, M.C.; Trouvé, G.; Gieré, R. Bottom ash of trees from Cameroon as fertilizer. Appl. Geochem. 2016, 72, 88-96. [CrossRef]

12. Vassilev, S.V.; Baxter, D.; Andersen, L.K.; Vassileva, C.G. An overview of the chemical composition of biomass. Fuel 2010, 89, 913-933. [CrossRef]

13. Röser, D.; Asikainen, A.; Raulund-Rasmussen, K.; Stupak, I. Sustainable Use of Forest Biomass for Energy: A Synthesis with Focus on the Baltic and Nordic Region; Springer Science \& Business Media: Berlin/Heidelberg, Germany, 2018.

14. Chaves, V.C.; Calvete, E.; Reginatto, F.H. Quality properties and antioxidant activity of seven strawberry (Fragaria $x$ ananassa duch) cultivars. Sci. Hortic. 2017, 225, 293-298. [CrossRef]

15. Contigiani, E.V.; Jaramillo-Sánchez, G.; Castro, M.A.; Gómez, P.L.; Alzamora, S.M. Postharvest Quality of Strawberry Fruit (Fragaria $x$ Ananassa Duch cv. Albion) as Affected by Ozone Washing: Fungal Spoilage, Mechanical Properties, and Structure. Food Bioprocess Technol. 2018, 11, 1639-1650. [CrossRef]

16. Duarte-Molina, F.; Gómez, P.L.; Castro, M.A.; Alzamora, S.M. Storage quality of strawberry fruit treated by pulsed light: Fungal decay, water loss and mechanical properties. Innov. Food Sci. Emerg. Technol. 2016, 34, 267-274. [CrossRef]

17. Li, Z. The effect of compressibility, loading position and probe shape on the rupture probability of tomato fruits. J. Food Eng. 2013, 119, 471-476. [CrossRef]

18. Li, Z.; Miao, F.; Andrews, J. Mechanical models of compression and impact on fresh fruits. Compr. Rev. Food Sci. Food Saf. 2017, 16, 1296-1312. [CrossRef] [PubMed]

19. Ji, W.; Qian, Z.; Xu, B.; Tang, W.; Li, J.; Zhao, D. Grasping damage analysis of apple by end-effector in harvesting robot. J. Food Process Eng. 2017, 40, 12589. [CrossRef]

20. Mahalik, N.P. Advances in packaging methods, processes and systems. Challenges 2014, 5, 374-389. [CrossRef]

21. Barrett, D.M.; Beaulieu, J.C.; Shewfelt, R. Color, flavor, texture, and nutritional quality of fresh-cut fruits and vegetables: Desirable levels, instrumental and sensory measurement, and the effects of processing. Crit. Rev. Food 2010, 50, 369-389. [CrossRef]

22. Bentini, M.; Caprara, C.; Martelli, R. Harvesting damage to potato tubers by analysis of impacts recorded with an instrumented sphere. Biosyst. Eng. 2006, 94, 75-85. [CrossRef]

23. Lu, R.F.; Abbott, J.A. Force/deformation techniques for measuring texture. Texture Food Solid Foods 2004, 2, 109-145. [CrossRef]

24. Bentini, M.; Caprara, C.; Martelli, R. Physico-mechanical properties of potato tubers during cold storage. Biosyst. Eng. 2009, 104, 25-32. [CrossRef]

25. Arévalos, A.; Redondo, E.; Insfrán, A. Daños mecánicos en productos de la industria agrícola: Revisión de la literatura. Lat. Am. J. Appl. Eng. 2019, 4, 1-14. Available online: http://lajae.uabc.mx/index.php/journal/article/view/108/80 (accessed on 23 December 2021). (In Spanish).

26. Hashemi, S.M.B.; Mousavi Khaneghah, A. Characterization of novel basil-seed gum active edible films and coatings containing oregano essential oil. Prog. Org. Coat. 2017, 110, 35-41. [CrossRef]

27. Hashemi, S.M.B.; Mousavi Khaneghah, A.; Ghaderi Ghahfarrokhi, M.; Eş, I. Basil-seed gum containing Origanum vulgare subsp viride essential oil as edible coating for fresh cut apricots. Postharvest Biol. Technol. 2017, 125, 26-34. [CrossRef]

28. Goli, A.; Khazaei, J.; Taheri, M.; Khojamli, A.; Sedaghat, A. Effect of mechanical damage on soybean germination. Int. Acad. J. Sci. Eng. 2016, 3, 48-58. Available online: https:/ / www.researchgate.net/publication/309858297_Effect_of_Mechanical_Damage_on_ Soybean_Germination (accessed on 23 December 2021).

29. Bank Danych o Lasach. Available online: www.bdl.lasy.gov.pl/portal/mapy (accessed on 23 December 2021).

30. World Reference Base for Soil Resources 2014. International soil classification system for naming soils and creating legends for soil maps. In World Soil Resources Reports; Food and Agriculture Organization of the United Nations: Rome, Italy, 2015; Volume 106, p. 203. Available online: https://www.fao.org/3/i3794en/I3794en.pdf (accessed on 23 December 2021).

31. Fertilization Recommendations. Part I. Limit Numbers for the Evaluation of the Content Macro-Soils and Micronutrients in Soils; Series P; IUNG-PIB: Puławy, Poland, 1990; Volume 44, pp. 1-26. (In Polish)

32. Skowera, B.; Jędrszczyk, E.; Kopcińska, J.; Ambroszczyk, A.M.; Kołtun, A. The effects of hydrothermal conditions during vegetation period on fruit quality of processing tomatoes. Pol. J. Environ. Stud. 2014, 23, 195-202. Available online: http://www. pjoes.com/The-Effects-of-Hydrothermal-Conditions-r-nduring-Vegetation-Period-on-Fruit-Quality,89183,0,2.html (accessed on 23 December 2021).

33. Si, Y.; Sankaran, S.; Knowles, N.R.; Pavek, M.J. Potato Tuber Length-Width Ratio Assessment Using Image Analysis. Am. J. Potato Res. 2017, 94, 88-93. [CrossRef]

34. Kiełbasa, P. Influence of potatoe field irrigation on physical properties of tubers. Acta Agroph. 2011, 17, 89-103. Available online: http:/ / www.acta-agrophysica.org/Influence-of-potatoe-field-irrigation-on-physical-properties-of-tubers, 107202,0,2 .html (accessed on 23 December 2021). (In Polish). 
35. Farhain, M.M.; Cheema, M.; Katanda, Y.; Nadeem, M.; Javed, B.; Thomas, R.; Saha, R.; Galagedara, L. Potential of developing podzolic soil-based potting media from wood ash, paper sludge and biochar. J. Environ. Manag. 2022, 301, 113811. [CrossRef]

36. Gruda, N.S. Increasing Sustainability of Growing Media Constituents and Stand-Alone Substrates in Soilless Culture Systems. Agronomy 2019, 9, 298. [CrossRef]

37. Nadeem, M.; Huong Pham, T.; Nieuwenhuis, A.; Ali, W.; Zaeem, M.; Ashiq, W.; Shah, S.; Gillani, M.; Manful, C.; Adigun, O.A.; et al. Adaptation strategies of forage soybeans cultivated on acidic soils under cool climate to produce high quality forage. Plant. Sci. 2019, 283, 278-289. [CrossRef] [PubMed]

38. Koch, M.; Naumann, M.; Pawelzik, E. The importance of nutrient management for potato production part i: Plant nutrition and yield. Potato Res. 2020, 63, 97-119. [CrossRef]

39. Larkin, R.P. Soil health paradigms and implications for disease management. Annu. Rev. Phytopathol. 2015, 53, 199-221. [CrossRef]

40. Doran, J.W.; Zeiss, M.R. Soil health and sustainability: Managing the biotic component of soil quality. Appl. Soil Ecol. 2000, 15, 3-11. [CrossRef]

41. Sharifi, M.; Cheema, M.; McVicar, K.; LeBlanc, L.; Fillmore, S. Evaluation of liming properties and potassium bioavailability of three Atlantic Canada wood ash sources. Can. J. Plant. Sci. 2013, 93, 1209-1216. [CrossRef]

42. Shabala, S.; Pottosin, I. Regulation of potassium transport in plants under hostile conditions: Implications for abiotic and biotic stress tolerance. Physiol. Plant. 2014, 151, 257-279. [CrossRef] [PubMed]

43. Wang, Y.; Wu, W.H. Potassium transport and signaling in higher plants. Annu. Rev. Plant Biol. 2013, 64, 451-476. [CrossRef] [PubMed]

44. Liu, H.Y.; Sun, W.N.; Su, W.A.; Tang, Z.C. Co-regulation of water channels and potassium channels in rice. Physiol. Plant. 2006, 128, 58-69. [CrossRef]

45. Walker, D.J.; Leigh, R.A.; Miller, A.J. Potassium homeostasis in vacuolate plant cells. Proc. Natl. Acad. Sci. USA 1996, 93, 10510-10514. [CrossRef]

46. Sanchez, P.D.C.; Hashim, N.; Shamsudin, R.; Nor, M.Z.M. Applications of imaging and spectroscopy techniques for nondestructive quality evaluation of potatoes and sweet potatoes: A review. Trends Food Sci. Technol. 2020, 96, 208-221. [CrossRef]

47. Storey, M. Chapter 21-The Harvested Crop. In Potato Biology and Biotechnology; Vreugdenhil, D., Bradshaw, J., Gebhardt, C., Govers, F., Mackerron, D.K.L., Taylor, M.A., Ross, H.A., Eds.; Elsevier Science: Amsterdam, The Netherlands, 2007; Volume 21, pp. 441-470. [CrossRef]

48. Roma, A.; Abete, M.C.; Brizio, P.; Picazio, G.; Caiazzo, M.; D'auria, J.L.; Esposito, M. Evaluation of Trace Elements in Potatoes (Solanum tuberosum) from a Suburban Area of Naples, Italy: The "Triangle of Death". J. Food Protect. 2017, 80, 1167-1171. [CrossRef] [PubMed]

49. Sierra, M.J.; Lopez-Nicolas, R.; Gonzalez-Bermudez, C.A.; Frontela-Saseta, C.; Millan, R. Cultivation of Solanum tuberosum in a former mining district for a safe human consumption integrating simulated digestion. J. Sci. Food Agr. 2017, 97, 5278-5286. [CrossRef] [PubMed]

50. Hajslova, J.; Schulzova, V.; Slanina, P.; Janne, K.; Hellenas, K.E.; Andersson, C. Quality of organically and conventionally grown potatoes: Four-year study of micronutrients, metals, secondary metabolites, enzymic browning and organoleptic properties. Food Addit. Contam. 2005, 22, 514-534. [CrossRef] [PubMed]

51. Zhang, B.; Huang, W.; Li, J.; Zhao, C.; Fan, S.; Wu, J.; Liu, C. Principles, developments and applications of computer vision for external quality inspection of fruits and vegetables: A review. Food Res. Int. 2014, 62, 326-343. [CrossRef]

52. Su, Q.; Kondo, N.; Li, M.; Sun, H.; Al Riza, D.F.; Habaragamuwa, H. Potato quality grading based on machine vision and 3D shape analysis. Comput. Electron. Agric. 2018, 152, 261-268. [CrossRef]

53. ElMasry, G.; Cubero, S.; Moltó, E.; Blasco, J. In-line sorting of irregular potatoes by using automated computer-based machine vision system. J. Food Eng. 2012, 112, 60-68. [CrossRef]

54. Mohd Ali, M.; Hashim, N.; Khairunniza Bejo, S.; Shamsudin, R. Rapid and nondestructive techniques for internal and external quality evaluation of watermelons: A review. Sci. Hortic. 2017, 225, 689-699. [CrossRef]

55. Thybo, A.K.; Szczypiński, P.M.; Karlsson, A.H.; Dønstrup, S.; Stødkilde-Jørgensen, H.S.; Andersen, H.J. Prediction of sensory texture quality attributes of cooked potatoes by NMR-imaging (MRI) of raw potatoes in combination with different image analysis methods. J. Food Eng. 2004, 61, 91-100. [CrossRef]

56. Abasi, S.; Minaei, S.; Jamshidi, B.; Fathi, D. Dedicated non-destructive devices for food quality measurement: A review. Trends Food Sci. Technol. 2018, 78, 197-205. [CrossRef] 